\title{
Cypriniformes of Borneo (Actinopterygii, Otophysi): An Extraordinary Fauna for Integrated Studies on Diversity, Systematics, Evolution, Ecology, and Conservation
}

\author{
ZOHRAH H. SULAIMAN ${ }^{1} \&$ R.L MAYDEN ${ }^{2}$ \\ ${ }^{1}$ Biological Science Programme, Faculty of Science, Universiti Brunei Darussalam, Tungku BE1410, Brunei Darussalam; \\ E-mail:zohrah.sulaiman@ubd.edu.bn \\ ${ }^{2}$ Department of Biology, 3507 Laclede Ave, Saint Louis University, St Louis, Missouri 63103, USA; E-mail:cypriniformes@ gmail.com
}

\begin{abstract}
Borneo Island is governed by the countries of Brunei Darussalam, Malaysia (Sabah and Sarawak) and Indonesia (Kalimantan) and is part of Sundaland. These countries have a high diversity of freshwater fishes, especially described and undescribed species of Cypriniformes; together these species and other flora and fauna represent an extraordinary opportunity for worldwide collaboration to investigate the biodiversity, conservation, management and evolution of Borneo's wildlife. Much of the fauna and flora of Borneo is under significant threat, warranting an immediate and swift international collaboration to rapidly inventory, describe, and conserve the diversity. The Sunda drainage appears to have been an important evolutionary centre for many fish groups, including cypriniforms (Cyprinidae, Balitoridae and Gyrinocheilidae); however, Northwestern Borneo (Brunei, Sabah and Sarawak) is not connected to Sundaland, and this disjunction likely explains the non-homogeneity of Bornean ichthyofauna. A previous study confirmed that northern Borneo, eastern Borneo and Sarawak shared a similar ichthyofauna, findings that support the general hypothesis for freshwater connections at one time between western Borneo and central Sumatra, and south Borneo and Java island.

Borneo is drained by five major rivers: (1) Rajang and Baram rivers in Sarawak, and (2) Kapuas, Mahakam and Barito rivers in Kalimantan. The Cypriniformes is the most diverse clade in Borneo, and it is represented by at least 285 species in 55 genera and eight major clades (Balitoridae, Cobitidae, Cyprinidae, Gyrinocheilidae, Leptobarbidae, rasborines, cultrines and Paedocyprididae); at least 147 (52\%) of these species are endemic to the incredibly diverse habitats of Borneo. Most fish faunal studies in Borneo have involved inventory and discovery; however, none to date have focused their efforts on the great biodiversity and systematics of Cypriniformes. In this paper we briefly discuss the general biodiversity of cypriniforms in Borneo, including recent revisions to the classification of the order through the Cypriniformes Tree of Life and Planetary Biodiversity Inventory efforts supported by the USA NSF basic science initiatives, in conjunction with researchers in countries of Borneo. It is our hope that this particular summary will galvanize individuals to increase worldwide collaborative and integrated efforts on the biodiversity of Cypriniformes, and incite lively discussions among a broad array of interested parties, including those involved in the recent and critically important "Heart of Borneo" initiative funded by all these countries and some NGOs.
\end{abstract}

Key words: Biodiversity, Borneo, Cypriniformes, Sundaland

\section{Introduction}

Borneo is widely known for its great floral and faunal diversity, but many areas of the island require further exploration (Clements et al. 2010; Ismail \& Din et al.1996-2001; Hall et al. 2002; Karim et al. 2004; Koh et al. 2010; MacKinnon et al. 1996; Mohd et al. 2003; Garbutt \& Prudent 2007; Wong \& Chan 1997 and references within these contributions). Diversity is especially high given the size of the island. Borneo is one of the few areas on the planet that has a combination of opportunities for rapidly advancing our understanding of the evolution, ecology, and fundamental conservation needs for its biodiversity. Much of the island has not been explored thoroughly, and many areas are not currently accessible. The ecosystems of Borneo are currently under assault from deforestation, plantation development, and major habitat changes brought on by humans. Once the obstacles for study have been overcome, a global consortium of scientists and nonscientists will be able to perform rapid assessments of the island's biodiversity. 
Borneo is ranked as the third largest island in the world, and consists of the independent Sultanate of Brunei Darussalam (northwest of Borneo), the Indonesian territory of Kalimantan (east, west and south of Borneo), and the Malaysian states of Sabah (north Borneo) and Sarawak (northwest to west Borneo) (Fig.1). The land area is 745,567 sq. $\mathrm{km}$ and is covered by a rich diversity of tropical rainforests. Only around $7 \%$ of the forests remain in a more or less intact condition (McGinley \& Hogan 2008). In 2007, Brunei, Indonesia and Malaysia made a declaration to protect 220,000 sq. km of pristine rainforest habitat that is now know as the "Heart of Borneo." As Borneo is near the equator, humidity is constantly high, temperatures in most parts of low-lying areas can reach $30^{\circ}-32^{\circ} \mathrm{C}$ during the daytime and many areas also receive high rainfall throughout the year. Borneo is drained by the Kapuas, Mahakam and Barito rivers in Kalimantan, and Rajang River in Sarawak. The terrain is generally low lying, with over half the island with elevations below $200 \mathrm{~m}$; however, the interior of Borneo is formed by a series of mountain ranges with elevations as great as over 3,000 m (Fig. 1).



FIGURE 1. Map of the Island of Borneo showing political divisions of Brunei Darussalam, Kalimantan, Sabah and Sarawak as well as its topographical features (from Tan 2006).

Borneo, the Malay Peninsula (Peninsula Malaysia), Java and Sumatra form the Sundaland, which lies in the drainage basin of the ancient Central or North Sunda River System (Fig. 2). The North Sunda River was formed by rivers from the western side of Borneo, central Sumatra and the western tip of the Malay Peninsula (Tija 1980). The flora and fauna of these regions are similar in their taxonomic composition, and have species and higher taxa shared between them. While the origins of this diversification in time and space have not been thoroughly 
investigated on a group-by-group basis, many phylogenetic analyses of species from these areas are emerging. These studies will provide a better understanding of the evolution of diversity in the Sundaland Region.

Herein, we provide a general background of the inventories of the freshwater fishes of Borneo. The origins of this diversity and the geological history that likely influenced biodiversity are reviewed. While a growing number of phylogenetic and inventory studies are occurring, the number of such studies done on individual areas or taxa is too numerous for us to summarize herein. Thus, we have identified some larger studies that have had significant impacts and do summarize other literature. We conclude with a clear message that the Cypriniformes represent one of the most diverse groups of fishes in Borneo, that their distributions on this island are not uniform, that there are many uniquely adapted species, and that a great emphasis must be given to more rapid inventory efforts by all countries of Borneo. Human induced environmental changes are outpacing our abilities to inventory biodiversity, and without an accurate understanding of this diversity, it cannot be conserved and protected, and we will likely never understand the unique nature of its origin.

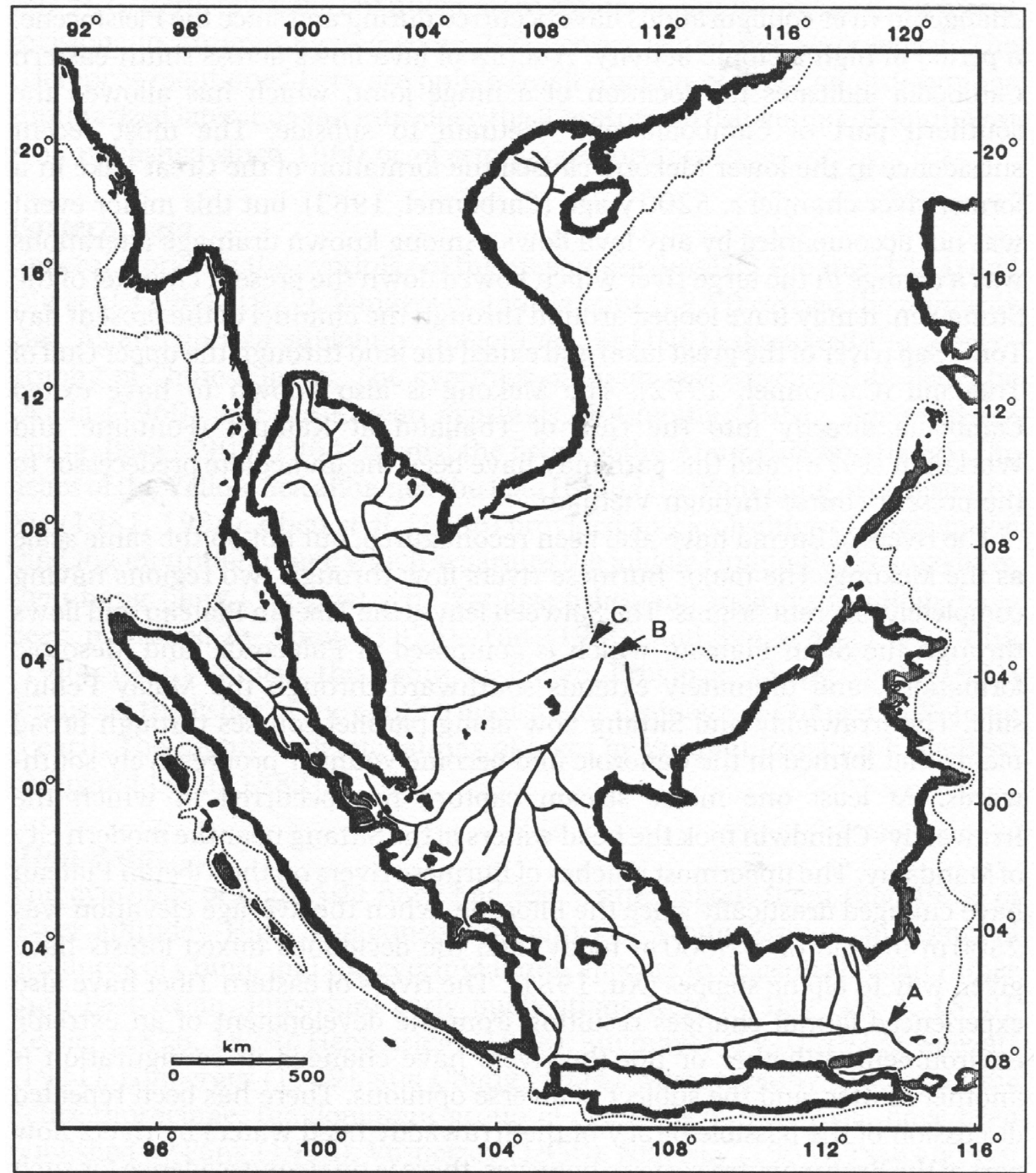

FIGURE 2. Extended Pleistocene rivers of Southeast Asia. (A) East Sunda River; (B) West Sunda River; (C) North Sunda River (from Rainboth 1991). 


\section{Materials and Methods}

The following books and papers were used as references for the Cypriniformes of Borneo: Inger \& Chin (1962, 1990, 2002); Roberts (1989); Kottelat et al. (1993), Choy \& Chin (1994); Parenti \& Meisner (2003); Kottelat \& Widjanarti (2005); Parenti \& Lim (2005); Tan (2006); Atack (2006) and Zohrah \& Ramlee (2007). Additional sampling of Brunei's rivers and lakes for freshwater fishes to add this overview. Fishes were captured using cast nets, hook and line, traps, gill nets and dip netting. We and other authors will report more on these recent surveys in a forthcoming publication.

\section{Brief Overview of Biogeographic Hypotheses}

Historically, prior to modern methods of phylogeny reconstruction, a series of hypotheses have been proposed to explain observed patterns in one group or replicate/nonreplicated patterns of distributions across taxa. One prominent hypothesis involves the fluctuation of sea level through time, thus permitting connections of landmasses and freshwater ecosystems. It has been hypothesized that during low water periods, land bridges provided connections between mainland Asia, Borneo, the western Indonesian islands, and the Philippine islands. These connections may have occurred multiple times. These connections have presumably occurred as a result of a series of low sea levels associated with the series of Pleistocene glaciations (2.4 mya-10,000 years) (Voris 2000). There were six events associated with lowered sea levels permitting connections of landmasses (75-120 m Below Present Level) during the past 0.25 million years (Chappel \& Shackleton 1986). Each of these proposed connections may have provided opportunities for floristic and faunistic exchanges.

Roberts (1989) observed that the Sunda drainage appears to have been an important area for the evolution of many fish groups, notably the Bagridae, Balitoridae, Cobitidae, Cyprinidae, Gyrinocheilidae, Homalopteridae, Siluridae and Pangasiidae. However, Northwestern Borneo (Sabah, Brunei and part of Sarawak) was not connected to the remaining Sundaland and the distributions of freshwater fish species/clades in Borneo, and surrounding regions where relatives occur, are not homogeneous. This faunal area contains taxa that are related to other Asian freshwater fishes but are not necessarily most closely related to those of the Sunda.

Within Borneo there are regions that warrant much closer examination through inventories and systematic studies to better understand not only the underlying reasons for differentiated faunas but also where the relatives of these areas occur in either Sundaland or other Asian areas. A study by Yap (2002) argued that the ichthyological communities of north Borneo, including Brunei, eastern Kalimantan and Sarawak, are quite similar in their constitution. The same pattern of similarity was observed for the communities of western Kalimantan and central Sumatra, as well as for southern Kalimantan and Java.

An earlier zoogeographical study on Sundaland noted the distributional patterns of faunal groups in the subregions of Borneo (Molengraaff \& Weber 1921). Beaufort (1951) discussed the distributions of fishes in Sundaland, which according to Rainboth (1991) provided students the first insight into drowned river basins of Southeast Asia. The general zoogeography of the freshwater fishes of North Borneo (Sabah) and of Borneo, in general, were discussed by Inger and Chin (1962). Finally, Rainboth (1991) showed that the faunas of rivers in Sumatra parallel those of the Kapuas River in western Kalimantan.

\section{Ichthyological Inventories and Biodiversity of Borneo}

Like other regions of southeast and East Asia, Borneo has a long but spotty history of inventory efforts by early researchers, and to this day many areas remain unexplored for diversity. This is a critical problem in the recognition of hotspots of biodiversity needed for the conservation, protection, and management of species, their necessary habitats and ecosystems. The latter needs aid in understanding the extent that forests are necessary, tree cover for protection of landscapes and maintaining cool water temperatures, and the absolute exclusion of nonnative plants and animals to these ecosystems. Until such time that inventories of these poorly inventoried areas are completed, we lack an ability to manage and protect this great biodiversity. The recently formed organization focused on conservation of areas of Borneo, The Heart of Borneo, serves as an excellent example of the urgent need for inventory efforts to determine and document, through validation with voucher specimens in well-funded and sustainable museums, the diversity of life in the regions of protection. 
Freshwater habitats of Borneo range from blackwater peat swamps, to rocky-hill streams in the mountainous interior, to forest-hill streams and partially-shaded forest streams with a substrate of mud sand, stones, leaf litter and/or fallen branches. Blackwaters of peat swamp forests have a high diversity of freshwater fishes, many of which are endemic. For example, $\mathrm{Ng}$ and Lim (1994) sampled 47 species of freshwater fishes from the North Selangor peat swamp forest (PSF), of which 14 are stenotopic to the PSF and represent $18 \%$ of the fish fauna in Peninsular Malaysia. The rich diversity of the PSF is further revealed with the discovery of one of the world's smallest vertebrates, Paedocypris (Kottelat et al. 2006) (formerly Cyprinidae, now Paedocyprididae; Chan \& Mayden 2009) from Southeast Asia and the new genus Fangfangia (Britz et al. 2011) from Kalimantan. The loss of just the PSF due to palm oil and other plantations represents a significant loss of biodiversity.

Well-known fish biologists, general naturalists, and ichthyologists conducted several early inventory efforts. Their historic efforts provided essential groundwork for future explorations. Pieter Bleeker first described 111 freshwater fish species from Borneo (Inger \& Chin 1962). Vaillant (1893) summarized what was known about the fauna and its diversity at that time. Subsequently, papers by Beaufort (1933), Boulenger (1894, 1899), Regan (1906), Seale (1910), Hora (1932), Herre (1933, 1940a, 1940b), Fowler (1905) and Brittan (1954) contributed significantly to the early studies of freshwater fishes in Borneo (Inger \& Chin 1962). These early efforts provided essential information that was used by later scientists to better understand the diversity, communities, and complexities of the regions. Since the 1960's, there have been many biological investigations into the region. One of the first such studies that was broad in scale was that of Rainboth (1991). This overview was the first to provide a relatively in depth description of the biologies and ecologies of Southeast Asian cyprinids. The regions included in this analysis included Borneo, Java, Sumatra, Peninsular Malaysia, Singapore, Thailand, Myanmar, Vietnam, Lao PDR and Cambodia.

The inventory and discovery of new freshwater fish species continued from these earlier studies of Borneo with the following important faunal compilations identified below by region. In more current-day literature, many have continued to contribute to the knowledge of the fauna as well as the island mass relative to global diversity of fishes. Inventory efforts by individual countries in Borneo include the following:

Brunei (Burridge 1992; Choy \& Chin 1994; Kottelat \& Lim 1995; Lim 1995; Parenti 1996; Parenti \& Meisner 2003; Tan \& Zohrah 2006; Zohrah \& Ramlee 2007).

Sabah (Inger \& Chin 1962, 1990, 2002; Witte \& Schmidt 1992; Lim \& Wong 1994; Nyanti 1995; Nyanti et al. 1995; Parenti 1996; Martin-Smith \& Tan 1998; Kottelat \& Widjanarti 2005).

Eastern Kalimantan (Kottelat et al. 1993; Kottelat 1995a; Kottelat \& Whitten 1996).

Western Kalimantan (Imaki et al.1981; Bànàrescu \& Bianco 1984; Giesen 1987; Roberts 1989; Kottelat et al. 1993; Kottelat 1995b; Kottelat \& Whitten 1996; Ng \& Kottelat 1996; Kottelat 1998; Rachmatika 1998; Tan \& Kottelat 1998; Dudley 2000; Motomura \& van Oijen 2003).

Sarawak (Parenti 1986; Brown \& Brown 1987; Burridge 1992; Kottelat \& Lim 1995; Lim \& Kottelat 1995; Parenti 1996; Nyanti et al. 1998; Ng \& Dodson 1999; Parenti \& Lim 2005; Atack 2006; Tan \& Leh 2006).

At a broader scale and in comparative analyses, Nelson (2006) estimated the number of freshwater fish species to be about 10,000 worldwide, 430 of which are from Borneo. Of this diversity more that $160(37 \%)$ of the species are endemic (McGinley \& Hogan 2008). However, other published literature reports 267 (62\%) freshwater fish species from nine genera as endemic to Borneo (Tan 2006); usual differences that occur due to time of studies and species and classification concepts held by the authors of such publications. The fish diversity of the Kapuas River in Kalimantan has been estimated to be 320 species (Inger \& Chin 2002). Within Sarawak alone, 254 fish species have been recorded (Atack 2006). In the waterways of Sabah 168 species have been recorded (Inger \& Chin 2002). Finally, across Brunei 125 species of freshwater fishes have been recorded. From these estimates, the Kapuas River and waterways of Sarawak currently have the highest diversity of fishes. While records of documented diversity will change with time and increased inventory efforts, currently the highest diversity list above can be explained, in part, by the connection of Kapuas River to the Sunda drainage. That the Sarawak basin was in close proximity to this large river system likely enhanced its diversity as well. Future studies on the phylogenetic relationships of species will be useful to test such hypotheses as to patterns of diversity and river connections, but only after much more inventory and proper sample collections are completed by professionals. The relatively low number of freshwater fishes in both Sabah and Brunei is not unexpected as both areas were not part of the Sunda drainage; however, Brunei has the highest ratio of freshwater fishes to area. 
It is clear that the ichthyofauna of Borneo is extremely diverse, and as our knowledge of the faunas from additional areas increases, this diversity is expected to grow rapidly. The same is true of many other areas of Asia that are poorly known or have been largely unexplored. Significantly more diversity is being discovered and information is being gained with increasing inventory efforts as emphasized in the Cypriniformes Tree of Life and Planetary Biodiversity Inventory initiatives coordinated with a global research community. Inventories are critical to the discovery of the fishes and their evaluation as to identification, naming, evidence for new species or supraspecific taxa and hypotheses of their evolutionary and biogeographic relationships, all of which feeds directly into global issues of community and ecosystem ecologies, water qualities, and impacts of climate change. This basic and essential data is also critical for the protection of the faunas as described above; however, unlike the historical efforts and some current efforts involving the inventories of many of these remote and unexplored areas researchers are urged to do more than simply capture, photograph and voucher specimens to document their existence. Many new local and global efforts are using methods to explore the variation in DNA of species from different areas and using these data to examine hypotheses of new diversity, assess genetic diversity, and reconstruct their evolutionary relationships. Grand efforts like the DNA Barcoding of Life have made extraordinary advances in some of these efforts. Other global efforts by consortiums of scientists working in collaboration have also made significant advances in the discovery of species and the reconstruction of their evolutionary relationships, through analyses of DNA variability and taxonomic studies. These efforts include the All Catfish Species Inventory (ACSI), All Cypriniformes Species Inventory (ACSI-II), and the Cypriniformes Tree of Life initiative (CToL). Concerted and collaborative efforts provide the most rapid means by which the scientific community of biodiversity research can better understand the diversity of the faunas and resolve how species evolve and are related to one another. Today, DNA variability likely represents the most rapid and informative means to address and achieve the above objectives. This effort of combining morphological and molecular data provides a powerful combination of effort to rapidly assess the biodiversity of an area and assess its genetic variability, diversity and evolution. Accomplishing this goal, however, is rarely built into any conservation plan or effort for poorly known areas or areas under severe threat like the peat swamp forests and the many other habitats occupied by cypriniforms and other fish groups in Borneo. Rather, emphasis and high priority should be placed not only on the inventory efforts but also the simultaneous sampling of specimens and essential tissues of the specimens, as well as their proper curation as vouchers in proper scientific museums that provide sustained support for adequate housing of such important samples for research and documentation. Such a more organized and thorough effort towards biodiversity studies will be the most rapid means through which we will see many important advances in our understanding of the origin, diversity, evolution, and biogeography of the cypriniform fishes, and other less diverse freshwater fishes of Borneo and surrounding regions.

\section{Results and Discussion}

\section{Attention to Recent Taxonomic Revisions of the Cypriniformes}

The order Cypriniformes is the most diverse group of freshwater fishes worldwide, and it has its greatest diversity in Southeast Asia. While the diversity and classification of the order Cypriniformes is currently in a state of flux, derived primarily from the global efforts from the CToL and ACSI-II, significant progress in the stability of major lineages has withstood multiple molecular phylogenetic analyses over the past decade that have involved both continued increased taxon and character sampling of species of Cypriniformes and outgroups (see Hillis 1996, 1998, Hillis et al. 2003, Heath et al. 2008 and references therein for significant impacts of sampling errors and stability of trees with improper sampling). Current-day investigations of the systematics of Cypriniformes and their higher classification are the first meaningful voyage into large scale and solidly supported phylogenetic relationships clearly necessary to justify a natural classification of the diversity. Historic dogma or stories as to similarities of group or groups argued to be linked by one or a few characters with no interpretation as to the polarity (plesiomorphic or apomorphic nature) of the character do not withstand the test of time and are not valid scientific hypotheses in the post-Hennigian age.

While nearly all of the targeted clades for taxonomic changes are supported by moderate to high levels of support values, our interpretation that the continued resolution and consistency of these lineages in this large and increasingly expanding Cypriniformes initiative speaks volumes about the naturalness of these supraspecific groups/taxa that have been elevated or described. Given these recent higher-level taxonomic changes, researchers, 
and those skeptical of such changes, must be clearly cognizant of and confront the actual fact that the traditional classification for Cypriniformes has never been examined via a meaningful phylogenetic survey or analysis that involved a wide enough scale of diversity to justify any traditional groupings in the traditional classifications (Nelson 2006), including those that continue to be used by many today. The fact is, the group has essentially been untouched phylogenetically and only small-scale analyses have been completed that. Thus, the need for a revised taxonomy and classification of the highly diverse lineage Cypriniformes of the Otophysi should not be a surprise to anyone familiar with this group, familiar with prior studies and with a phylogenetic background and understanding of the foundational principles underlying the discipline (sensu Hennig 1996, Wiley 1981, Wiley \& Lieberman 2011). The broad-based and global phylogenetic surveys conducted for close to a decade of intense and focused studies, using either genetic or morphological data, have clearly supported taxonomic changes relative to the subfamilies elevated to families, tribes to subfamilies, new families described, and one new supraorder (see Chen \& Mayden 2009; Chen et al. 2009; Mayden \& Chen 2010; Mayden et al. 2009; Saitoh et al. 2011; Tang et al. 2010, 2011; Yang \& Mayden 2010, 2011; Yang et al. 2012).

Nelson (2006) identified the order as consisting of six families, 321 genera and roughly 3,268 species. Among the different families at that time was the family Cyprinidae. This family was identified as the largest group with at least 220 genera and about 2,420 species. Like the order, the greatest diversity in this family exists in Southeast Asia with roughly 70 endemic genera (Rainboth 1991). The other subfamilies and tribes within this family were much smaller; however, it must be noted that these historical hypotheses of taxonomic diversity and classification had not been vetted by underlying phylogenetic analyses needed to corroborate monophyletic families, subfamilies, tribes, and genera. Rather, at the time of his publication Nelson simply had to rely on the existing, largely unchanged and traditional classification of Cypriniformes that has existed for decades. Again, this classification was not supported by thorough phylogenetic analysis and was largely derived from overall external morphological phenetic similarity or gross anatomical similarity perceived by individual researchers. In recent studies, many subfamilies, tribes, and genera share no apomorphic characters to support their existence in a natural classification and thus there is no basis for much of the traditionally used classification, save some groups within Cobitoidea and some lineages in Cyprinoidea. Rather, many of the traditional groupings recognized formally in our classification or informally amongst experts have been historically retained only by the fact that they either have a distinctive morphological (of unknown character polarity) (Type I Groupings) or are simply lumped together because of no clear placement for the taxa (Type II Groupings). Finally, the continued recognition and adherence to the traditional classification of these unsupported supraspecific taxa likely precludes their use as evidence for relationships and conservation purposes will be misleading to the biological community.

\section{Diversity of Cypriniformes in Borneo and Surrounding Regions}

As to the biodiversity of Southeast Asian Cypriniformes, under the CToL and ACSI-II projects, as well as efforts of many other globally involved researchers examining relationships but at a smaller scale, the new classification discussed above for this diverse order is emerging. Many of the current estimates of supraspecific diversity do not account for several species (placed in specific genera) and genera that have been described since Rainboth's study. The validity as to the placement of these newly discovered and described genera, and species in particular and the monophyly of genera or other supraspecific taxa await formal evaluation through ongoing phylogenetic analyses, preferably within a context of a diverse array of species and character types. While a more stable classification of the order is evolving, there still remains portions of the phylogeny, many with species not represented from Borneo waterways, that are not yet stable, due only to the lack of samples for phylogenetic evaluation. The inclusion of many genera and species from Borneo (especially endemics) in these studies will provide for a more stable classification.

Given the above constraints in our understanding of lineage composition, currently, within the order and across Southeast Asia, China has the greatest diversity at the family-group level (including several of the traditionally hypothesized subfamilies, tribes and subtribes) (Rainboth 1991). Species of the subfamily Cyprinine, including such common species as the Crucian carp, goldfish and common carp, represent the dominant subfamily with over $60 \%$ of the total number of cyprinid species in Southeast Asia (sensu Rainboth 1991). The second most diverse cyprinid group is Danioninae (or "Rasborinae" by some; neither group being monophyletic) (sensu Rainboth 1991). In 2006 Nelson attempted to estimate the diversity included in the then recognized eleven subfamilies (Type 
I and II groupings), as well as several genera that at that time could not be confidently assigned to any of the existing subfamilies (Type II Groupings). Recent phylogenetic studies providing evidence for sister-group relationships are refining hypotheses of relationships to provide a more robust and informative classification of these fishes (see above). As the order is currently in a major transition with respect to relationships and classification, until such time species from the faunas of Borneo and other regions in Asia are included it is impossible to know with high levels of confidence the number of families, subfamilies, genera or any other supraspecific assignment of these species of this Asian fauna.

In all, the Borneo fauna is known to contain five families (Gyrinocheilidae, Balitoridae, Cobitidae, Cyprinidae, Paedocyprididae,), 56 genera and 286 species of cypriniform fishes (Kottelat et al. 1993; Tan 2006; personal observations and studies); 28 of these genera alone have been recognized under the traditionally recognized Cyprinidae. As addressed above, this classification largely lacks phylogenetic support; however, it is a fact that the current number of cypriniform species in Borneo represents $66 \%$ of its total freshwater fauna and is growing rapidly with continued inventory and study. Much is to be gained studying the distributional patterns of these fishes across Borneo and in surrounding, yet disjunct freshwater areas. We do know that the Kapuas River of Kalimantan alone contains 4 families, 50 genera, and 140 species of cypriniforms (Roberts 1989). The Rajang River of Sarawak includes 4 families, 31 genera and 79 species of cypriniforms (Parenti \& Lim 2005; Chen \& Mayden 2009; Mayden \& Chen 2010). Waterways of Sabah are known to include 3 families, 28 genera and 65 of cypriniforms species (Inger \& Chin 2002). In Brunei the aquatic habitats are home to 4 families, 26 genera and 61 species of Cypriniforms (Zohrah, personal observation and data).

Below, in our discussion of the diversity of cypriniform species in Borneo, we make an effort to identify species within the revised classification from recent phylogenetic, revisionary studies. For this Borneo fauna, species and genera formerly assigned to the historically recognized Family Cyprinidae are herein allocated to their more recent assignments of genera and species under the family classification identified above. Under the revision, the cultrine and rasborine clades represent new, undescribed family groups. Table 1 shows the revision for the historically recognized Family Cyprinidae for diversity in Brunei, Sabah, Sarawak and Kalimantan. As such, fourteen genera were initially assigned to Cyprinidae in Brunei; following the revisionary analysis and classification recommendation by Chen and Mayden (2009) and Mayden and Chen (2010), only nine genera are now assigned to Cyprinidae. Similarly Kalimantan had 38 genera initially assigned under the traditional Cyprinidae, but is now reduced to 24 genera (Table 1).

Amongst the genera of the Cypriniformes, the genus Gastromyzon has the highest number of species (36) within Borneo and of these species, 19 have only recently been identified and described as new species. This is not all that surprising as not only has the fauna only recently undergone greater scrutiny with increased inventories in some areas, but the general concept of what constitutes a species in nature has evolved considerably (Mayden \& Wood 1995; Mayden 1997, 2002; Wiley \& Mayden 2000). Species of this genus also inhabit headwater streams where they are more likely to become isolated and diverge more rapidly. Another speciose genus is Rasbora, with at least 16 species hypothesized to be endemic to Borneo. Both the Rajang River in Sarawak and Danau Sentarum National Park in western Kalimantan host fourteen species of Rasbora. Like these two examples of genera, many other taxonomic groups in Borneo await tests of monophyly and more accurate assessments of their diversity. However, given the current state of our knowledge as to the diversity of Borneo fishes, with many areas remaining to be investigated, the actual diversity of Cypriniformes and endemism within drainages, countries, or supraspecific groupings must be an area of continuing investigation and growth for fruitful investigations of biodiversity like the Heart of Borneo program.

Chen and Mayden (2009 and see references therein) suggested the elevation of five subfamilies to families: Cyprinidae, Acheilognathidae, Tincidae, Leuciscidae and Gobionidae. Based on this and other phylogenetic studies, the Superfamily Cyprinoidea now includes at least ten monophyletic clades, most of which are recognized as families. These include the five families mentioned above, as well as the Cultrine clade, Leptobarbidae, Psilorhynchidae, two unrelated "Rasborine" clades, Oxygastrinae, and Tanichthyidae (Chen \& Mayden 2009). Similar family-level recognition of lineages was argued in molecular analyses by Chen et al. (2009). Finally, in a detailed molecular and morphological evaluation and analysis of the relationships of various lineages of Cyprinoidea and Cobitoidea Mayden and Chen (2010) evaluated the phylogenetic placement of the enigmatic genus Paedocypris. This was done in the broad context of taxon, by major lineages, and character sampling to avoid known influences on relationships due to taxon and character sampling. These analyses supported the family rankings of Mayden and Chen (2009) and supported Paedocypris as the sister group to the Cobitoidea plus 
Cyprinoidea. However, with the inclusion of morphological data provided in a previous morphological study the sister relationship of Paedocyprididae to Cobitoidea plus Cyprinoidea was argued to be the most parsimonious hypothesis of sister-group relationships.

TABLE 1. Genera of Cyprinoidea (Cypriniformes) from Borneo by Country and Region. Names based on revised classification (see text for citations).

\begin{tabular}{|c|c|c|c|c|}
\hline \multirow[t]{2}{*}{ Family } & \multicolumn{4}{|l|}{ Genera (nos.) } \\
\hline & Brunei & Kalimantan & Sarawak & Sabah \\
\hline \multirow[t]{26}{*}{ Cyprinidae } & Barbonymus & Albulicthys & Barbonymus & Barbonymus \\
\hline & Hampala & Amblyrhyncihys & Cosmochilus & Hampala \\
\hline & Lobocheilus & Balantioheilos & Hampala & Labiobarbus \\
\hline & Megalops & Barbonymus & Labiobarbus & Lobocheilus \\
\hline & Nematabramis & Barbichthys & Lobocheilus & Nematabramis \\
\hline & Osteochilus & Cosmochilus & Nematabramis & Osteochilus \\
\hline & Paracrossochilus & Eirmotus & Osteochilus & Paracrossochilus \\
\hline & Puntioliptes & Epalzeorhynchos & Paracrossochilus & Puntioliptes \\
\hline & Systomus & Fangfangia & Puntioliptes & Schismatorhynchus \\
\hline & (9) & Hampala & Sundadanio & Systomus \\
\hline & & Kalimantania & Schismatorhynchos & (10) \\
\hline & & Labeo & Systomus & \\
\hline & & Labiobarbus & $(12)$ & \\
\hline & & Lobocheilus & & \\
\hline & & Nematabramis & & \\
\hline & & Neobarynotus & & \\
\hline & & Mystacoleucus & & \\
\hline & & Osteochilus & & \\
\hline & & Paracrossochilus & & \\
\hline & & Pectenocypris & & \\
\hline & & Puntioliptes & & \\
\hline & & Rasborichthys & & \\
\hline & & Schismatorhynchos & & \\
\hline & & Systomus & & \\
\hline & & Thynnichthys & & \\
\hline & & $(25)$ & & \\
\hline \multirow[t]{7}{*}{ Other Cyprinid genera } & Cycloceilicthys & Boraras & Cyclocheilicthys & Crosscoceilus \\
\hline & Tor & Crossocheilus & Garra & Cyclocheilicthys \\
\hline & (2) & Cyclocheilicthys & Tor & Garra \\
\hline & & Garra & (3) & Tor \\
\hline & & Parachela & & (4) \\
\hline & & Tor & & \\
\hline & & (6) & & \\
\hline \multirow[t]{2}{*}{ Cultrine clade } & & Macrochirichthys & Macrochirichthys & \\
\hline & & (1) & (1) & \\
\hline \multirow[t]{7}{*}{ Rasborine clade } & Rasbora & Chela & Rasbora & Chela \\
\hline & Oxygaster & Luciosoma & Oxygaster & Luciosoma \\
\hline & (2) & Opsarius & Luciosoma & Rasbora \\
\hline & & Oxygster & (3) & (3) \\
\hline & & Rasbora & & \\
\hline & & Thryssocypris & & \\
\hline & & (6) & & \\
\hline Leptobarbidae & Leptobarbus & Leptobarbus & Leptobarbus & Leptobarbus \\
\hline \multirow[t]{2}{*}{ Paedocyprinidae } & & Paedocypris & Paedocypris & \\
\hline & & (1) & (1) & \\
\hline
\end{tabular}




\section{Endemism}

Over $60 \%$ of the freshwater fish species of Borneo are endemic. In Sabah, $42 \%$ of the fish species are endemic, $63 \%$ of which are endemic to Borneo (Inger \& Chin 2002). Table 2 provides a list of cypriniform species endemic to Borneo. A total of 147 species from 38 genera and seven families (Balitoridae, Cobitidae, Cyprinidae, Gyrinocheilidae, Leptobarbidae, and the Cultrine and Rasborine Clades) are endemic to Borneo. Several of these major clades have high endemism. The family Cyprinidae has 11 genera and 35 species that are endemic. Other interesting cyprinid genera include the monotypic Fangfangia, two species of Boraras and one species each of the genera Crossocheilus, Cyclocheilicthys, Kalamantania and Garra. The Rasborine clade includes four genera and 20 endemic species. The family Balitoridae has the highest number of endemic species and half of these endemics are species of the genus Gastromyzon (Zohrah et al. 2006). This family has 13 genera and 71 species that are endemic. Cobitidae is currently recognized as having three genera and 11 species endemic to Borneo. Leptobarbidae has one genus and three species. Finally, the Gyrinocheilidae has only three species total, one of which is endemic to Borneo.

Across the island, endemism of cypriniform fishes is related to the size of the political areas (with larger area having greater waterways and topographic relief). Kalimantan has 79 species (53.7\%), Sabah has 54 species (36.7\%), Sarawak has 35 species (23.8\%) and Brunei has 16 species (10.9\%) endemic. The highest endemism in Kalimantan occurs in water bodies that were historically part of the Sunda River drainage. It is also interesting to note that the fish species found in Sabah and Kalimantan are confined to their respective regions, likely due to their historic rivers and riverine connections. The topography and disconnection of Sabah from the remainder of Sundaland is hypothesized as the underlying mechanism for this noted isolation. Only three endemic cypriniform fish species, Barbonymus colligwoodii, Hampala bimaculata and Paracroscheillus acerus, are common in all regions (Table 2). Others are either confined to one, two or three areas. For example, Garra borneensis is present in all regions except Brunei. Kalimantan has the highest number of fishes confined to its basins. The genera Gastromyzon, Neogastromyzon and Hypergastromyzon are limited to hilly regions of Borneo, potentially explaining the lack of species from Kalimantan, a region including vast areas of lowland swamp forests (Tan 2006). A number of species are, however, restricted to single basins. As some examples Gastromyzon cranbrooki, Gastromyzon venustus and Neogastromyzon brunei, all confined to Temburong basin in Brunei.

\section{Biodiversity of Cypriniformes and Aquatic Ecosystems}

While Borneo is an incredibly diverse region and maintains many endemic taxa, we predict that our understanding of this biodiversity and its overall biology, diversity, ecology, etc. is grossly underestimated. With increasing exploratory and taxonomic studies in the coming years all of the families and genera identified herein (including Tables) are predicted to include more species, many being endemic to Borneo. Government agencies of each of the countries of Borneo and those representing areas surrounding Borneo, the many associated NGO partners, and coordinated conservation efforts (e.g., Heart of Borneo), and groups of scientists can together bring to bear strong united efforts to inventory of the critically threatened freshwater fishes of Borneo. Coordinated efforts will be most productive as many of the needs, country requirements, resources, and educational opportunities can be shared and leveraged to strongly enhance our account of species diversity. This effort will in turn provide the necessary underlying biodiversity information for the use in other fields of biology, resource management, forestry, etc. Together, this will permit a more complete and more rapid understanding of the fauna, as well as develop strategic plans for those conservation, strategically located national parks and other efforts that are currently not under control (e.g., introductions and farming of exotic species) that are endangering the endemic flora and fauna of the island. 
TABLE 2. Cypriniform species endemic to Borneo as divided by Brunei, Sabah, Sarawak and Kalimantan. *taxon is Lobocheilos cf. bo. Families of Cypriniformes include A. Cyprinidae, B. Other Cyprinid Genera, C. Rasborine Clade, D. Leptobarbidae, E. Paedocyprinidae, F. Balitoridae, G. Cobitididae, H. Gyrinocheilidae.

\begin{tabular}{|c|c|c|c|c|c|}
\hline A. Cyprinidae & Borneo & Brunei & Sabah & Sarawak & Kalimantan \\
\hline 1. Barbonymus collingwoodii & $\mathrm{X}$ & $\mathrm{X}$ & $\mathrm{X}$ & $\mathrm{X}$ & $\mathrm{X}$ \\
\hline 2. Barbonymus strigatus & $\mathrm{X}$ & & $\mathrm{X}$ & & \\
\hline 3. Barbonymus sunieri & $\mathrm{X}$ & & & & $\mathrm{X}$ \\
\hline 4. Hampala bimaculata & $\mathrm{X}$ & $X$ & $\mathrm{X}$ & $\mathrm{X}$ & $X$ \\
\hline 5. Labiobarbus sabanas & $\mathrm{X}$ & & $\mathrm{X}$ & & \\
\hline 6. Lobocheilos bo & $\mathrm{X}$ & $*$ & $\mathrm{X}$ & $*$ & $\mathrm{X}$ \\
\hline 7. Nematabramis alestes & $X$ & & $X$ & & \\
\hline 8. Nematabramis everetti & $\mathrm{X}$ & & $\mathrm{X}$ & & \\
\hline 9. Nematabramis borneensis & $\mathrm{X}$ & & $\mathrm{X}$ & & \\
\hline 10. Nematabramis steindachneri & $\mathrm{X}$ & & & & $\mathrm{X}$ \\
\hline 11. Osteochilus bellis & $\mathrm{X}$ & & & & $\mathrm{X}$ \\
\hline 12. Osteochilus chini & $\mathrm{X}$ & & $\mathrm{X}$ & & \\
\hline 13. Osteochilus harrisoni & $\mathrm{X}$ & & $\mathrm{X}$ & & \\
\hline 14. Osteochilus ingeri & $\mathrm{X}$ & & $\mathrm{X}$ & & \\
\hline 15. Osteochilus kelabai & $\mathrm{X}$ & & & & $\mathrm{X}$ \\
\hline 16. Osteochilus pentalineatus & $\mathrm{X}$ & & & & \\
\hline 17. Osteochilus partilineatus & $\mathrm{X}$ & & & & $\mathrm{X}$ \\
\hline 18. Osteochilus repang & $\mathrm{X}$ & & & & $\mathrm{X}$ \\
\hline 19. Osteochilus sarawakensis & $\mathrm{X}$ & & $X$ & $X$ & \\
\hline 20. Parachela cyanea & $\mathrm{X}$ & & & & $\mathrm{X}$ \\
\hline 21. Parachela ingerkongsi & $\mathrm{X}$ & & & & $\mathrm{X}$ \\
\hline 22. Paracrosrossochilus acerus & $\mathrm{X}$ & $\mathrm{X}$ & $\mathrm{X}$ & $\mathrm{X}$ & $\mathrm{X}$ \\
\hline 23. Paracrosschilus vittatus & $\mathrm{X}$ & $X$ & & $X$ & $\mathrm{X}$ \\
\hline 24. Pectenocypris balena & $\mathrm{X}$ & & & & $X$ \\
\hline 25. Systomus anchisporus & $\mathrm{X}$ & & & & $\mathrm{X}$ \\
\hline 26. Systomus banksi & $\mathrm{X}$ & $\mathrm{X}$ & & $\mathrm{X}$ & $\mathrm{X}$ \\
\hline 27. Systomus everetti & $\mathrm{X}$ & & & & $\mathrm{X}$ \\
\hline 28. Systomus endecanalis & $\mathrm{X}$ & & & & $\mathrm{X}$ \\
\hline 29. Systomus kuchingensis & $\mathrm{X}$ & & & $\mathrm{X}$ & \\
\hline 30. Systomus foerschi & $X$ & & $X$ & & \\
\hline 31. Systomus pentazona & $\mathrm{X}$ & $\mathrm{X}$ & & & $\mathrm{X}$ \\
\hline 32. Systomus phambocellatus & $\mathrm{X}$ & & & & $\mathrm{X}$ \\
\hline 33. Systomus trifiscatus & $\mathrm{X}$ & & & & $\mathrm{X}$ \\
\hline 34. Systomus sealei & $\mathrm{X}$ & & & & $X$ \\
\hline 35. Thynnichthys vaillanti & $\mathrm{X}$ & & & & $\mathrm{X}$ \\
\hline TOTAL & $35 / 35$ & $7 / 35$ & $14 / 35$ & $8 / 35$ & $23 / 35$ \\
\hline
\end{tabular}

\begin{tabular}{|c|c|c|c|c|c|}
\hline B. Other Cyprinid genera & Borneo & Brunei & Sabah & Sarawak & Kalimantan \\
\hline 1. Boraras briggitae & $\mathrm{X}$ & & & & $\mathrm{X}$ \\
\hline 2. Boraras merah & $X$ & & & & $X$ \\
\hline 3. Garra borneensis & $\mathrm{X}$ & & $\mathrm{X}$ & $\mathrm{X}$ & $X$ \\
\hline 4. Crossocheilus nigriloba & $\mathrm{X}$ & & & & $\mathrm{X}$ \\
\hline 5. Cyclocheilicthys jantochchir & $\mathrm{X}$ & & & & $\mathrm{X}$ \\
\hline TOTAL & $5 / 5$ & $0 / 5$ & $1 / 5$ & $1 / 5$ & $5 / 5$ \\
\hline
\end{tabular}




\begin{tabular}{|c|c|c|c|c|c|}
\hline C. Rasborine Clade & Borneo & Brunei & Sabah & Sarawak & Kalimantan \\
\hline 1. Luciosoma pelegrinii & $\mathrm{X}$ & & & & $\mathrm{X}$ \\
\hline 2. Osparius borneensis & $\mathrm{X}$ & & & & $\mathrm{X}$ \\
\hline 3. Rasbora axelrodi & $\mathrm{X}$ & & & & $\mathrm{X}$ \\
\hline 4. Rasbora borneensis & $\mathrm{X}$ & & & & $\mathrm{X}$ \\
\hline 5. Rasbora ennealepis & $\mathrm{X}$ & & & & $\mathrm{X}$ \\
\hline 6. Rasbora hubbsi & $\mathrm{X}$ & & $\mathrm{X}$ & & \\
\hline 7. Rasbora johanae & $\mathrm{X}$ & & & & $\mathrm{X}$ \\
\hline 8. Rasbora kalbarensis & $\mathrm{X}$ & & & & $\mathrm{X}$ \\
\hline 9. Rasbora kottelati & $\mathrm{X}$ & $\mathrm{X}$ & & $\mathrm{X}$ & \\
\hline 10. Rasbora laticlavia & $\mathrm{X}$ & & & & $\mathrm{X}$ \\
\hline 11. Rasbora rutteni & $\mathrm{X}$ & & $X$ & & \\
\hline 12. Rasora sarawakensis & $\mathrm{X}$ & & & $X$ & $\mathrm{X}$ \\
\hline 13. Rasbora semilineata & $\mathrm{X}$ & & $\mathrm{X}$ & & \\
\hline 14. Rasbora subtilis & $\mathrm{X}$ & & & & X \\
\hline 15. Rasbora trifasciata & $\mathrm{X}$ & & & & $\mathrm{X}$ \\
\hline 16. Rasbora tubbi & $\mathrm{X}$ & $\mathrm{X}$ & X & & \\
\hline 17. Rasbora tuberculata & $X$ & & & $\mathrm{X}$ & $X$ \\
\hline 18. Rasbora volzi & $X$ & & & & $X$ \\
\hline 19. Thryssocrypris ornithostoma & $\mathrm{X}$ & & & & $\mathrm{X}$ \\
\hline 20. Thryssocrypsis smaragdinus & $X$ & & & & $\mathrm{X}$ \\
\hline TOTAL & $20 / 20$ & $2 / 20$ & $4 / 20$ & $3 / 20$ & $15 / 20$ \\
\hline
\end{tabular}

\begin{tabular}{|c|c|c|c|c|c|}
\hline D. Leptobarbidae & Borneo & Brunei & Sabah & Sarawak & Kalimantan \\
\hline 1. Leptobarbus hosii & $\mathbf{X}$ & & $\mathbf{X}$ & & \\
\hline 2. Leptobarbus melanopterus & $\mathbf{X}$ & & $\mathbf{X}$ & & $\mathbf{X}$ \\
\hline 3. Leptobarbus melanotaenia & $\mathbf{X}$ & & $\mathbf{X}$ & & $\mathbf{X}$ \\
\hline TOTAL & $3 / 3$ & $\mathbf{0 / 3}$ & $3 / 3$ & $\mathbf{0 / 3}$ & $2 / 3$ \\
\hline
\end{tabular}

\section{E. Paedocyprinidae}

\begin{tabular}{lccccc}
\hline 1. Paedocypris micromegethes & & & $\mathbf{X}$ & \\
\hline TOTAL & $\mathbf{0} / \mathbf{1}$ & $\mathbf{0 / 1}$ & $\mathbf{0 / 1}$ & $\mathbf{0 / 1}$ & $\mathbf{0 / 1}$ \\
\hline
\end{tabular}

\begin{tabular}{|c|c|c|c|c|c|}
\hline F. Balitoridae & Borneo & Brunei & Sabah & Sarawak & Kalimantan \\
\hline 1. Gastromyzon aequabilis & $\mathrm{X}$ & & $\mathrm{X}$ & & \\
\hline 2. Gastromyzon aeroides & $X$ & $X$ & $\mathrm{X}$ & & \\
\hline 3. Gastromyzon arunigros & $X$ & & $X$ & & \\
\hline 4. Gastromyzon barrio & $X$ & & & $\mathrm{X}$ & \\
\hline 5. Gastomyzon borneensis & $\mathrm{X}$ & & $\mathrm{X}$ & & \\
\hline 6. Gastromyzon contractus & $X$ & & & & $X$ \\
\hline 7. Gastromyzon cornusaccus & $X$ & & $X$ & & \\
\hline 8. Gastromyzon cranbrooki & $\mathrm{X}$ & $\mathrm{X}$ & & & \\
\hline 9. Gastromyzon crenastus & $\mathrm{X}$ & & & $\mathrm{X}$ & \\
\hline 10. Gastromyzon ctenocephalus & $X$ & & & $X$ & $X$ \\
\hline 11. Gastromyzon danumensis & $\mathrm{X}$ & & $X$ & & \\
\hline 12. Gastromyzon embalohensis & $\mathrm{X}$ & & & & $\mathrm{X}$ \\
\hline 13. Gastromyzon extrosus & $\mathrm{X}$ & & $\mathrm{X}$ & & \\
\hline
\end{tabular}




\begin{tabular}{|c|c|c|c|c|c|}
\hline F. Balitoridae (Continued) & Borneo & Brunei & Sabah & Sarawak & Kalimantan \\
\hline 14. Gastromyzon farragus & $\mathrm{X}$ & & & $\mathrm{X}$ & \\
\hline 15. Gastromyzon fasciatus & $\mathrm{X}$ & & & $\mathrm{X}$ & \\
\hline 16. Gastromyzon ingeri & $\mathrm{X}$ & & $\mathrm{X}$ & & \\
\hline 17. Gastromyzon introrsus & $\mathrm{X}$ & & $\mathrm{X}$ & & \\
\hline 18. Gastromyzon katibasensis & $\mathrm{X}$ & & & $\mathrm{X}$ & \\
\hline 19. Gastromyzon lepidogaster & $\mathrm{X}$ & $\mathrm{X}$ & $\mathrm{X}$ & & $\mathrm{X}$ \\
\hline 20. Gastromyzon megalepis & $\mathrm{X}$ & & & $\mathrm{X}$ & \\
\hline 21. Gastromyzon monticola & $\mathrm{X}$ & & $\mathrm{X}$ & & \\
\hline 22. Gastromyzon ocellatus & $\mathrm{X}$ & & & $\mathrm{X}$ & \\
\hline 23. Gastromyzon omaticauda & $\mathrm{X}$ & & $\mathrm{X}$ & & $\mathrm{X}$ \\
\hline 24. Gastromyzon pariclavis & $\mathrm{X}$ & & $\mathrm{X}$ & & \\
\hline 25. Gastromyzon praestans & $\mathrm{X}$ & & & & $\mathrm{X}$ \\
\hline 26. Gastromyzon psiloetron & $\mathrm{X}$ & & & & $\mathrm{X}$ \\
\hline 27. Gastromyzon punctulatus & $\mathrm{X}$ & $\mathrm{X}$ & & $\mathrm{X}$ & \\
\hline 28. Gastromyzon ridens & $\mathrm{X}$ & & & & $\mathrm{X}$ \\
\hline 29. Gastromyzon russulus & $\mathrm{X}$ & & & & $\mathrm{X}$ \\
\hline 30. Gastromyzon scitulus & $\mathrm{X}$ & & & $\mathrm{X}$ & \\
\hline 31. Gastromyzon spectabilis & $\mathrm{X}$ & & $\mathrm{X}$ & & \\
\hline 32. Gastromyzon stellatus & $\mathrm{X}$ & & & $\mathrm{X}$ & \\
\hline 33. Gastromyzon umbrus & $\mathrm{X}$ & & $\mathrm{X}$ & & $\mathrm{X}$ \\
\hline 34. Gastromyzon venustus & $\mathrm{X}$ & $\mathrm{X}$ & & & \\
\hline 35. Gastromyzon viriosus & $\mathrm{X}$ & & & $\mathrm{x}$ & \\
\hline 36. Gastromyzon zebrinus & $\mathrm{X}$ & & & & $\mathrm{X}$ \\
\hline 37. Glaniopsis denudate & $\mathrm{X}$ & & $\mathrm{X}$ & & \\
\hline 38. Glaniopsis gossei & $\mathrm{X}$ & & $\mathrm{X}$ & & \\
\hline 39. Glaniopsis hanitschi & $\mathrm{X}$ & & $\mathrm{X}$ & & \\
\hline 40. Glaniopsis multiradiata & $\mathrm{X}$ & & $\mathrm{x}$ & & \\
\hline 41. Homaloptera stephensoni & $\mathrm{X}$ & & $\mathrm{X}$ & $\mathrm{X}$ & $\mathrm{X}$ \\
\hline 42. Pseudohomaloptera tatergani & $\mathrm{X}$ & & & & $\mathrm{X}$ \\
\hline 43. Homaloptera weberi & $\mathrm{X}$ & & & & $\mathrm{X}$ \\
\hline 44. Homaloptera yuwonoi & $\mathrm{X}$ & & & & $\mathrm{X}$ \\
\hline 45. Hypergastromyzon eubranchus & $\mathrm{X}$ & & & $\mathrm{X}$ & \\
\hline 46. Hypergastromyzon humilis & $\mathrm{X}$ & & & & $\mathrm{X}$ \\
\hline 47. Katibasia insidiosa & $\mathrm{X}$ & & & & \\
\hline 48. Nemacheilus elegantissimus & $\mathrm{X}$ & & & & \\
\hline 49. Nemacheilus kapuasensis & $\mathrm{X}$ & & & & $\mathrm{X}$ \\
\hline 50. Nemacheilus lactogenus & $\mathrm{X}$ & & & & $\mathrm{X}$ \\
\hline 51. Nemacheilus lactogenus & $\mathrm{X}$ & & & & $\mathrm{X}$ \\
\hline 52. Nemacheilus longipectoralis & $\mathrm{X}$ & & $\mathrm{X}$ & & $\mathrm{X}$ \\
\hline 53. Nemacheilus olivaceus & $\mathrm{X}$ & & $\mathrm{X}$ & & \\
\hline 54. Nemacheilus saravacensis & $\mathrm{X}$ & & & & $\mathrm{x}$ \\
\hline 55. Neogastromyzon brunei & $\mathrm{X}$ & $\mathrm{X}$ & & & \\
\hline 56. Neogastromyzon chini & $\mathrm{X}$ & & & $\mathrm{X}$ & \\
\hline 57. Neogastromyzon crassiobex & $\mathrm{X}$ & & $\mathrm{X}$ & & $\mathrm{X}$ \\
\hline 58. Neogastromyzon kottelati & $\mathrm{X}$ & & & & $\mathrm{X}$ \\
\hline
\end{tabular}

......continued on the next page 


\begin{tabular}{|c|c|c|c|c|c|}
\hline F. Balitoridae (Continued) & Borneo & Brunei & Sabah & Sarawak & Kalimantan \\
\hline 59. Neogastromyzon nieuwenhuisii & $\mathrm{X}$ & & & & $\mathrm{X}$ \\
\hline 60. Neogastromyzon pauciradiatus & $\mathrm{X}$ & & & $\mathrm{X}$ & \\
\hline 61. Neogastromyzon sp. 'Baram’ & $\mathrm{X}$ & & & $\mathrm{X}$ & \\
\hline 62. Parhomaloptera microstoma & $\mathrm{X}$ & & & & \\
\hline 63. Protomyzon aphelocheilus & $\mathrm{x}$ & & $\mathrm{X}$ & & \\
\hline 64. Protomyzon borneensis & $\mathrm{X}$ & & $\mathrm{X}$ & & \\
\hline 65. Portomyzon griswoldi & $\mathrm{X}$ & & $\mathrm{x}$ & & \\
\hline 66. Protomyzon whiteheadi & $\mathrm{x}$ & & $\mathrm{X}$ & & \\
\hline 67. Schistura maculiceps & $\mathrm{X}$ & & & & $\mathrm{X}$ \\
\hline 68. Sundoreonectes obesus & $\mathrm{X}$ & & & & $\mathrm{X}$ \\
\hline 69. Sundoreonectes sabanus & $\mathrm{X}$ & & $\mathrm{X}$ & $\mathrm{X}$ & \\
\hline 70. Vaillantella cinnamomea & $\mathrm{X}$ & & & & $\mathrm{X}$ \\
\hline 71. Vaillantela euepiptera & $\mathrm{X}$ & & & & \\
\hline TOTAL & $71 / 71$ & $6 / 71$ & $27 / 71$ & $18 / 71$ & $24 / 71$ \\
\hline
\end{tabular}

\begin{tabular}{|c|c|c|c|c|c|}
\hline G. Cobitidae & Borneo & Brunei & Sabah & Sarawak & Kalimantan \\
\hline 1. Acanthopsoides robertsi & $\mathrm{X}$ & & & & $\mathrm{X}$ \\
\hline 2. Acanthopsoides octoactinotos & $\mathrm{X}$ & & $\mathrm{X}$ & & \\
\hline 3. Lepidocephalicthys lorentzi & $\mathrm{X}$ & & & & $\mathrm{X}$ \\
\hline 4. Lepidocephalicthys sandakenensis & $\mathrm{X}$ & & $\mathrm{X}$ & & \\
\hline 5. Lepidocephalus spectrum & $\mathrm{X}$ & & & & $\mathrm{X}$ \\
\hline 6. Pangio agma & $\mathrm{x}$ & $\mathrm{X}$ & & $\mathrm{X}$ & \\
\hline 7. Pangio alternans & $\mathrm{X}$ & & & & $\mathrm{X}$ \\
\hline 8. Pangio borneensis & $\mathrm{X}$ & & & & $\mathrm{X}$ \\
\hline 9. Pangio incognito & $\mathrm{X}$ & & & $\mathrm{X}$ & \\
\hline 10. Pangio mariarum & $\mathrm{X}$ & & $\mathrm{X}$ & & $\mathrm{X}$ \\
\hline 11. Pangio superba & $\mathrm{X}$ & & & & $\mathrm{X}$ \\
\hline TOTAL & $11 / 11$ & 1/11 & 3/11 & $2 / 11$ & $7 / 11$ \\
\hline
\end{tabular}

\begin{tabular}{lccccc}
\hline H. Gyrinocheilidae & Borneo & Brunei & Sabah & Sarawak & Kalimantan \\
\hline $\begin{array}{l}\text { 1. Gyrinocheilidae pustulosus } \\
\text { TOTAL }\end{array}$ & $\mathrm{X}$ & & & & $\mathrm{X}$ \\
\hline GRAND TOTAL & $\mathbf{1}$ & $\mathbf{0}$ & $\mathbf{0}$ & $\mathbf{0}$ & $\mathbf{1}$ \\
\hline
\end{tabular}

\section{Essential Importance of Information on Fish Biodiversity of Borneo}

The fish fauna of the Sundaland, especially the highly diverse clade of Cypriniformes, offers a faunal diversity important to not only biodiversity and conservation efforts, but a seriously and significant unique natural laboratory for studies of evolution, biogeography, ecology, and ecosystem dynamics. This, however, can only be successful and serve as an international example of rapid studies in these areas with the above described coordinated efforts of government agencies, universities, museums, scientists from around the globe all working together and sharing data, information and specimens. The easiest and most efficient mechanism for this is to have a joint treaty amongst those countries of Borneo and surrounding countries for scientific studies and sampling permits. Each country, or a joint treaty of countries, must also develop state-of-the-art museums and facilities for the storage and 
curation of samples of organisms and studied by scientists, a data repository, and agreements that must be signed by anyone working in these regions that permit museums and other researchers access to any and all data and specimens. Only through these agreements can the united countries of Borneo ensure that science on their biodiversity will progress forward through peer-reviewed papers. Specimens, tissues and/or data cannot be removed from the country without proper authorization through a centralized and expedient and rapid process. All data captured from any specimens/other sources (DNA sequences, photographs, histology, physiology, environmental parameters) must be the property of the countries and maintained there with approval of scientists to use them. With the proper facilities and an expeditious system for allowing workers to obtain proper permits for sampling and export of approved materials, and specimen curation and data storage, are not provided in a state-ofthe-art manner then the system will not work and will breakdown. This will eventually lead to a loss of biodiversity because the rate of data and specimen acquisition and inventory, respectively, will not be fast enough to save the diversity. Likewise a system that does not provide opportunities for in-country and out-of-country researchers to obtain official permits in a expeditious and timely manner will ultimately lead to bio-piracy and the lack of resources coming to the individual countries from a plethora of funding agencies for research from around the globe. Joint and collegial studies are essential for rapid ecosystem and biodiversity investigations today.

Only through the advances in the above in-country issues and scientific collaboration for the regions of Borneo and surrounding areas will it be possible to move from simple, untestable ad hoc hypotheses or long-held dogma as to the origin and functional natures within the composite fauna to vital testable hypotheses. For example, largescale hypotheses of species relationships, biogeography, and linkages among multiple patterns of diversification potentially linked to cycles of land connections/sea level fluctuation - and the evolutionary rates and patterns, the evolutionary origins of morphological, ecological and many other attributes of clades and individual species. This information is also absolutely linked to the fundamentals of discovery and distribution of diversity and phylogenetic reconstructions that provide for more informative classification of the diversity to better reflect their relationships in the Sundaland and areas outside this diverse area. Equipped with this fundamental information, the various data being gathered simultaneously and via joint efforts, can all be interpreted in an evolutionary context for a more complete perspective leading to better practices and to testable hypotheses of community and ecosystem patterns and functions. Only through this process and cooperation can we reveal critical functions such as keystone species of communities and ecosystems, influence of surrounding terrestrial habitats on these aquatic systems, and many other discoveries that also demand keen conservation, protection and monitoring efforts so as to not simply watch the loss of this unique diversity.

With the availability of the rich information as to the geological and drainage history of this general area, many important advances can be achieved in studying its fauna and flora. With a history of fluctuating sea levels connections between areas of the region opportunities for dispersal, isolation and speciation also fluctuated, all leading to the rapid increase in diversity. Again, this represents an outstanding natural laboratory model system for evolutionary biology, but only with knowledge of the diversity and the biology and phylogenetic relationships of its species, endemic or not. With these fluctuations may have come unprecedented rates of diversification, as well as the evolution of highly specialized morphological, ecologies, behaviors, etc. Thus, the well-known geology, climatic history, and river systems, together with the lack of major events that could have eliminated diversity large-scale extinction of portions of the fauna, (i.e., glaciation; however, inundation of areas by saltwater fluctuations would have been problematic unless species could seek refuge upstream) the intact biodiversity of this expansive region may be intact as to its evolution. However, the gross loss of both terrestrial and aquatic habitats in recent years, however, has likely lead to the extinctions of species with small distributions in these susceptible areas. Yet, delaying any efforts to fully understand the origin and history of this fauna and the region through any impediments to scientific work and in-country growth of proper infrastructure of trained professions, facilities, protected areas, the gross data available for synthesis to expedite research, etc. will be a fatal mistake.

\section{Acknowledgements}

We thank Universiti Brunei Darussalam for research grant [UBD/PNC2/RG/1(217)], and conference and leave grant to attend the International Conference on All Cypriniformes Species Inventory, 13-15 January 2012 in Chiang Mai, Thailand (to ZHS). We also thank the USA National Science Foundation for research funding (DEB 0240184, EF 0431326, DEB-0817027, DBI-0956370, and DEB-1021840 to RLM). 


\section{References}

Atack, K. (2006) A Field Guide to The Fishes of Kuching Rivers, Sarawak, Malaysia Borneo. Natural History Publications (Borneo), Kota Kinabalu, 200 pp.

Bànàrescu, P \& Bianco, P.G. (1984) A contribution to fish fauna of Kapuas River, Kalimantan Barat, Indonesia Borneo: Cyprinidae. Cybium, 8, 59-70.

Beaufort, L.F.de (1933) On some new or rare species of Ostariophysi from the Malay Peninsula and a new Betta from Borneo. Bulletin of Raffles Museum, 8, 31-36.

Beaufort, L.F.de. (1951) Zoogeography of the Land and Inland Waters. Sidgwick \& Jackson, London, 208 pp.

Boulenger, G.A. (1894) Descriptions of new freshwater fishes from Borneo. Annals and Magazine of Natural History, 13, $245-251$.

Boulenger, G.A. (1899) Descriptions of new homalopterid fishes from Borneo. Annals and Magazine of Natural History, 4, $228-229$.

Brittan, M.R. (1954) A revision of the Indo-Malayan freshwater fish genus Rasbora. Philippines Institute of Science \& Technology, Manilla, $224 \mathrm{pp}$.

Britz, R., Kottelat, M. \& Tan, H.H. (2011) Fangfangia spinicleithralis, a new genus and species of miniature cyprinid fish from the peat swamp forests of Borneo (Teleostei: Cyprinidae). Ichthyological Exploration of Freshwaters, 9, 267-272.

Brown, A. \& Brown, B. (1987) A survey of freshwater fishes of the family Belontiidae in Sarawak. Sarawak Museum Journal, 37, $155-170$.

Burridge, M.E.(1992) Systematics of the Acanthophthalmus kuhlii complex (Teleostei: Cobitidae), with the description of a new species from Sarawak \& Brunei. Copeia, 1992, 172-186.

Chappel, J. \& Shackleton, N.J. (1986) Oxygen isotopes and sea level. Nature, 324, 137-140.

Chen, W-J. \& Mayden, R.L. (2009) Molecular systematics of the Cyprinoidea (Teleostei; Cypriniformes), the world's largest clade of freshwater fishes: Further evidence from six nuclear genes. Molecular Phylogenetics and Evolution, 52, 544-549.

Chen, W.-J., Lheknim, L. \& Mayden, R.L. (2009) Molecular phylogeny of the Cobitoidea (Teleostei: Cypriniformes) revisited: position of enigmatic loach Ellopostoma resolved with six nuclear genes. Journal of Fish Biology, 75, 2197-2208.

Choy, S.C \& Chin, P.K. (1994) Freshwater fishes from the headwaters of the Belalong-Temburong river system, Brunei Darussalam, Borneo. Raffles Bulletin of Zoology, 42, 757-774.

Clements, R., Rayan, D.M., Abdul Wahab, A.Z., Venkataraman, A., Alfred, R., Payne, J., Ambu, L., \& Sharma, D.S.K. (2010) Trio under threat: can we secure the future of rhinos, elephants and tigers in Malaysia? Biodiversity and Conservation, 19, $1115-1136$.

Dudley, R.G. (2000) The fishery of Danau Sentarum. Borneo Research Bulletin, 31, 261-306.

Fowler, H.W. (1905) Some fishes from Borneo. Proceedings of the National Academy of Natural Sciences of Philadelphia, 57, 455-523.

Garbutt, N. \& Prudente, J. C. (2007) Wild Borneo: The Wildlife and Scenery of Sabah, Sarawak, Brunei, and Kalimantan. MIT Press, Cambridge, Massachusetts, 176 pp.

Giesen, W. (1987) Danau Sentarum wildlife Reserve-inventory, ecology and management guidelines. World Wildlife Fund Report to Directorate of Forest Protection \& Nature Conservation (PHPA), Bogor, 284 pp.

Hall, L.S., Richards, G.C. \& Abdullah, M.T. (2002) The bats of Niah National Park, Sarawak. Sarawak Museum Journal, 78, $255-282$.

Heath, T.A., Hedtke, S.M, Hillis, D.M. (2008) Taxon sampling and the accuracy of phylogenetic analyses. Journal of Systematics and Evolution, 46, 239-257.

Hennig, W. (1966) Phylogenetic systematics. University of Illinois Press, Urbana, Illinois, 263 pp.

Herre, A.W.C.T. (1933) A checklist of fishes from Sandakan, British North Borneo. Journal of Pan-Pacific Research Institute, 8, $2-5$.

Herre, A.W.C.T. (1940a) New species of fishes from the Malay Peninsula and Borneo. Bulletin of the Raffles Museum, 16, 5-26.

Herre, A.W.C.T. (1940b) Additions to the fish fauna of Malaya and notes on rare or little known Malayan and Bornean fishes. Bulletin of the Raffles Museum, 16, 27-61.

Hillis, D.M. (1996) Inferring complex phylogenies. Nature, 383, 130-131.

Hillis, D.M. (1998) Taxonomic sampling, phylogenetic accuracy, and investigator bias. Systematic Biology, 47, 3-8.

Hillis, D.M., Pollock, D.D., McGuire, J.A., Zwickl, D.J. (2003) Is sparse taxon sampling a problem for phylogenetic inference? Systematic Biology, 52, 124-126.

Hora, S.L. (1932) Classification, bionomics and evolution of Homalopterid fishes. Memoirs of the Indian Museum, 12, $263-330$.

Imaki, A., Kawamoto, A. \& Suzuki, A. (1981) Results of an ichthyological survey in the Kapuas River, West Kalimantan, Indonesia. Research Institute of Evolutionary Biology Special Publication, 1, 33-54.

Inger, R.F. \& Chin, P.K. (1962) The freshwater fishes of North Borneo. Fieldiana: Zoology, 45, 1-268.

Inger, R.F. \& Chin, P.K. (1990) The freshwater fishes of North Borneo. Fieldiana: Zoology, 45, 1-268. Sabah Zoological Society reprint of 1962 monograph.

Inger, R.F.\& Chin, P.K. (2002) The freshwater fishes of North Borneo. Fieldiana: Zoology, 45, 1-268. Second reprint (2002) of Inger \& Chin (1962), with a revised supplementary chapter, Natural History Publications (Borneo), Kota Kinabalu.

Ismail, G. \& Din, L. (1996-2001) Scientific Journey Through Borneo Series. Universiti Malaysia sarawak, Kota Samrahan.

Karim, C., Tuen, A.A. \& Abdullah, M.T. (2004) Mammals. Sarawak Museum Journal Special Issue 6, 80, 221-234.

Koh, L.P., Ghazoul, J., Butler, R.A., Laurance, W.F., Sodhi, N.S., Mateo Vega, J. \& Bradshaw, C.J.A. (2010) Wash and spin cycle threats to tropical biodiversity. Biotropica, 42, 67-71.

Kottelat, M. (1995a) The fishes of the Mahakam River, East Borneo, an example of the limitations of biogeographic analyses and the need for extensive fish surveys in Indonesia. Tropical Biodiversity, 2, 401-426.

Kottelat, M. (1995b) Four new species of fishes from the middle Kapuas basin, Indonesian Borneo (Osteichthyes: Cyprinidae and Belontiidae). Raffles Bulletin of Zoology, 43, 51-64.

Kottelat, M. (1998) Homaloptera yuwonoi, a new species of hillstream loach from Borneo, with a new generic name for $H$. thamicola 
(Teleostei: Balitoridae). Ichthyological Exploration of Freshwaters, 9, 267-272.

Kottelat, M. \& Lim, K.K.P. (1995) Freshwater fishes of Sarawak and Brunei Darussalam: a preliminary annotated checklist. Sarawak Museum Journal, 48, 227-256.

Kottelat, M. \& Whitten, A.J. (1996) Freshwater fishes of Western Indonesia and Sulawesi: additions and corrections. Periplus, Hong Kong, 8 pp.

Kottelat, M. \& Widjanarti, E. (2005) The fishes of Danau Sentarum National Park and the Kapuas Lakes area, Kalimantan Barat, Indonesia. In: Yeo, D.C.J. \& Kottelat, M. (Eds), Southeast Asian Fish Freshwater Diversity, Raffles Bulletin of Zoology, Supplement 13, pp. 139-173.

Kottelat, M., Whitten, A.J., Kartikasari, S.N. \& Wirjoatmodjo, S. (1993) Freshwater fishes of Western Indonesia and Sulawesi. Periplus Editions, Hong Kong, 221 pp.

Kottelat, M., Britz, R., Hui, T.T \& Witten, K-E. (2006) Paedocypris, a new genus of Southeast Asian Cyprinid fish with a remarkable sexual dimorphism, comprises the world's smallest vertebrate. Proceedings of the Royal Society B, 273, 895-899.

Lim, K.K.P. (1995) Rasbora kottelati, a new species of Cyprinid fish from North-western Borneo. Raffles Bulletin of Zoology, 43, $65-74$.

Lim, K.K.P. \& Wong, A. (1994) Fishes of the Kinabatangan Basin, Sandakan District, Sabah, East Malaysia. Sabah Museum Journal, $1,39-71$.

Lim, K.K.P. \& Kottelat, M. (1995) Carinotetraaodon salivator, a new species of pufferfish from Sarawak, Malaysia (Teleostei: Tetraodontidae). Japanese Journal of Ichthyology, 41, 359-365.

MacKinnon, K., Hatta, G., Halim, H., \& Mangalik, A. (1996) The ecology of Kalimantan. Periplus Editions, Hong Kong, p.802.

Martin-Smith, K.M. \& Tan, H.H. (1998) Diversity of freshwater fishes from Eastern Sabah: Annotated checklist for Danum Valley and a consideration for inner- and intra-catchment variability. Raffles Bulletin of Zoology 46, 573-604.

Mayden, R.L., \& Wood, R.M. (1995) Systematics, species concepts, and the evolutionarily significant unit in biodiversity and conservation biology. Special Publication, American Fisheries Society, 17, 58-113.

Mayden, R.L. (1997) A hierarchy of species concepts: the denouement in the saga of the species problem, In: Claridge, M.F., Dawah, H.A. and Wilson, M.R. (Eds) Species: The Units of Biodiversity. Chapman and Hall Ltd., London, pp. 381-424.

Mayden, R.L. (2002) On biological species, species concepts, and individuation in the natural world. Fish and Fisheries, 2, 1-26.

Mayden, R.L. \& Chen, W-J. (2010) The world's smallest vertebrate species of the Genus Paedocypris: A new family of freshwater fishes and the sister group to the world's most diverse clade of freshwater fishes (Teleostei: Cypriniformes). Molecular Phylogenetics and Evolution, 57, 152-75

Mayden, R.L., Chen, W.-J., Bart, H.L., Doosey, M.H., Simons, A.M., Tang, K.L., Wood, R.M., Agnew, M.K., Yang, L., Hirt, M.V., Clements, M.D., Saitoh, K., Sado, T., Miya, M. \& Nishida. M. (2009) Reconstructing the phylogenetic relationships of the earth's most diverse clade of freshwater fishes-order Cypriniformes (Actinopterygii: Ostariophysi): A case study using multiple nuclear loci and the mitochondrial genome. Molecular Phylogenetics and Evolution, 51, 500-514.

McGinley, M. \& Hogan, C.M. (2008) Biological Diversity in Sundaland. Encyclopedia of Earth. Available from http: // www.eoearth.org (Date of access: 12/01/11).

Mohd, A.J., Maryanto, I., Kartono, A.P. \& Abdullah, M.T. (2003) Diversity, Relative Abundance and Conservation of Chiropterans in Kayan Mentarang National Park, East Kalimantan, Indonesia. Sarawak Museum Journal, 79, 251-265.

Molengraaff, G.A.F. \& Weber, M. (1921) On the relation between the Pleistocene glacial period and the origin of the Sunda Sea (Java and south China Sea) and its influence on the distribution of coral reefs and on the land and freshwater fauna. Proceedings Koniglijke Akademie van Wtenschappen te Amsterdam, 23, 395-439.

Motomura, H. \& van Oijen, M.J.O. (2003) Polynemus kapuasensis, a new threadfin (Perciformes: Polynemidae) from western Kalimantan, Indonesia and a redescription of P. multifilis Temminck \& Schelgel, 1843. Zoologische Mededelingen, 77, $393-407$.

Nelson, J.S. (2006) Fishes of the World. John Wiley \& Sons, New Jersey, 601 pp.

Ng, P.K.L. \& Lim, K.K.P. (1994) Diversity and conservation of blackwater fishes in Peninsular Malaysia in the North Selangor peat swamp forest. Hydrobiologia, 285, 203-218.

Ng, H.H. \& Kottelat, M. (1996) Akysis fuscus, a new species of catfish (Teleostei: Akysidae) from the Kapuas basin, Borneo. Ichthyological Exploration of Freshwaters, 7, 19-26.

Ng, H.H. \& Dodson, J.J. (1999) Morphological and genetic descriptions of a new species of catfish, Hemibagrus chrysops from Sarawak, East Malaysia, with an assessment of phylogenetic relationships (Teleostei: Bagridae). The Raffles Bulletin of Zoology, 47, 45-57.

Nyanti, L. (1995) Fish fauna of Sayap-Kinabalu Park, Sabah. In: Ismail, G. \& Din, L. (Eds), A Scientific Journey through Borneo. Sayap-Kinabalu Park, Sabah. Universiti Malaysia Sarawak, Pelanduk Publications, pp.189-199.

Nyanti, L., Ghaffar, M.A. \& Samad, A. (1995) An ichthyological survey of Tawau Hills Park Sabah. In: Ismail, G., Omar, S. \& Din, L. (Eds), A Scientific Journey through Borneo. Tawau Hills Park. Sabah. Universiti Malaysia Sarawak, Pelanduk Publications, pp. 173-189.

Nyanti, L., Ling, T.Y. \& Adha, K. (1998) Freshwater fishes from Bario, Kelabit Highlands, Sarawak. In: Ismail, G. \& Din, L. (Eds). A Scientific Journey through Borneo, Bario. The Kelabit Highlands of Sarawak. Universiti Malaysia Sarawak, Pelanduk Publications, pp. 183-191.

Parenti, L.R. (1986) Bilateral asymmetry in phallostethid fishes (Actherinomorpha) with description of a new species from Sarawak. Proceedings of the Californian Academy of Sciences, 44, 225-236.

Parenti, L.R. (1996). Phylogenetics systematics and biography of phallostethid fishes (Atherinomorpha, Phallostethidae) of northwestern Borneo, with description of new species. Copeia, 1996, 703-712.

Parenti, L.R. \& Meisner, A.D. (2003) Fishes of the Belait River. Brunei Museum Journal, 10, 17-54.

Parenti, L.R. \& Lim, K.K.P. (2005) Fishes of the Rajang Basin, Sarwak, Malaysia. In: D.C.J. Yeo \& M. Kottelat (Eds), Southeast 
Asian Freshwater Fish Diversity. Raffles Bulletin of Zoology, Singapore Suppl. 13, pp. 175-208

Rachmatika, I. (1998) Gastromyzon embalohensis, a new species of sucker loach (Teleostei: Balitoridae) from the Bentuang Karimun National Park, West Kalimantan, Indonesia. Raffles Bulletin of Zoology 46, 651-659.

Rainboth, W.J. (1991) Cyprinids of South East Asia. In: Winfield, I.J. \& Nelson, J.S. (Eds), Cyprinid Fishes Systematics, Biology and Exploitation, Chapman and Hall, London, pp. 175-208.

Regan, C.T. (1906) Descriptions of five new freshwater fishes from Sarawak, Borneo, collected by Dr. C. Hose. Annals \& Magazine of Natural History, 18, 66-68.

Roberts, T.R. (1989) The freshwater fishes of Western Borneo (Kalimantan Barat, Indonesia). Proceedings of the California Academy of Sciences, 14, 1-210.

Saitoh, K., Sado, T., Doosey, M.H., Bart, H.L., Inoue, J.G., Nishida, M., Mayden, R. L. \& Miya, M. (2011) Evidence from mitochondrial genomics supports the lower Mesozoic of South Asia as the time and place of basal divergence of cypriniform fishes (Actinopterygii: Ostariophysi). Zoological Journal of Linnaean Society, 161, 633-662.

Seale, A. (1910) Fishes of Borneo, with descriptions of four new species. Philippine Journal of Science, 5, 263-288.

Tan, H.H. (2006) The Borneo Suckers. Natural History Publications (Borneo), Kota Kinabalu, 245 pp.

Tan, H.H. \& Kottelat, M. (1998) Two new species of Betta (Teleostei: Osphronemidae) from the Kapuas basin, Kalimantan Barat, Borneo. Raffles Bulletin of Zoology, 46, 41-51.

Tan, H.H \& Leh, C.U.M. (2006) Three new species of Gastromyzon (Teleostei: Balitoridae) from southern Sarawak. Zootaxa, 1126, $1-19$.

Tan, H.H. \& Zohrah H.S. (2006) Three new species of Gastromyzon (Teleostei: Balitoridae) from Temburong basin, Brunei Darussalam. Zootaxa, 1117, 1-19.

Tang, K., Conway, W., Agnew, M.K., Chen, W.-J., Hirt, M.V., Sado, T., Schneider, L.M., Freyhof, J., Swartz, E., Vidthayanon, C., Bart, H.L., Miya, M., Saitoh, K., Simons, A.M., Wood, R.M. \& Mayden. R.L. (2010) Systematics of the subfamily Danioninae (Teleostei: Cypriniformes: Cyprinidae). Molecular Phylogenetics and Evolution, 57, 189-214.

Tang, K.L., Agnew, M.K., Chen, W-J., Raley, M.E., Sado, T., Schneider, L.M., Yang, L., Bart, H.L., He, S., Liu, H., Miya, M., Saitoh, K., Simons, A.M., Wood, R.M. \& Mayden. R.L. (2011) Phylogeny of the gudgeons (Teleostei: Cyprinidae: Gobioninae). Molecular Phylogenetics and Evolution, 61, 103-124

Tija, H.D. (1980) The Sunda shelf, Southeast Asia. Zeitschrift Fur Geomorphologie, N.F., 24, 405-27.

Vaillant, L. (1893) Contribution a l'etude de la faune ichthyologique de Borneo. Nouveu Archives du Museum Paris, 5, $23-114$.

Voris, H.K. (2000) Maps of Pleistocene sea-levels in South East Asia: shorelines, river systems, time durations. Journal of Biogeography, 27, 1153-1167.

Wiley, E.O. (1981) Phylogenetics, the theory and practice of phylogenetic systematics. John Wiley and Sons, Inc., New York.

Wiley, E.O., \& Lieberman, B.S. (2011) Phylogenetics: Theory and Practice of Phylogenetic Systematics, 2nd Edition. John Wiley \& Sons, Inc., Hoboken, New Jersey, 432 pp.

Wiley, E. O. \& Mayden, R.L. (2000) The evolutionary species concept. In: Wheeler, Q.D. \& Meier, R. (Eds), Species Concepts and Phylogenetic Theory: A Debate. Columbia University Press, New York, pp.70-89.

Witte, K.-E. \& Schmidt, J. (1992) Betta brownorum, a new species of anabantoids. Ichthyological Exploration of Freshwaters, 2, 305330.

Wong, K.M. \& Chan, C.L. (1997) Mt Kinabalu: Borneo's Magic Mountain. Natural History Publications, Kota Kinabalu. 95 pp.

Yang, L., Arunachalam, M., Sado, T., Levin, B.A., Golubtsov, A.S., Freyhof, J., Friel, J.P., Chen, W.-J., Hirt, M.V., Manickam, R., Agnew, M.K., Simons, A.M., Saitoh, K., Miya, M., Mayden, R.L. \& He, S.P. (2012) Molecular phylogeny of the cyprinid tribe Labeonini (Teleostei: Cypriniformes). Molecular Phylogenetics and Evolution, Submitted.

Yang, L. \& Mayden, R. L. (2010) Phylogenetic Relationships, Subdivision, and Biogeography of the Cyprinid Tribe Labeonini (sensu Rainboth, 1991) (Teleostei: Cypriniformes), with Comments on the Implications of Lips and Associated Structures in the Labeonin Classification. Molecular Phylogenetics and Evolution, 54, 254-265.

Yang, L. \& Mayden, R.L. (2011) Molecular phylogeny of the cyprinid subfamily Cyprininae (Teleostei: Cypriniformes), with emphasis on the tribe Cyprinini sensu stricto and its relationship with the tribe Barbini. Zoologica Scripta, 39, 527-550.

Yap, S.Y. (2002) On the distributional patterns of Southeast-East Asian freshwater fish and their history. Journal of Biogeography, 29, $1187-1199$.

Zohrah, H.S., Hui, T.H., Lim, K.K.P. \& Ng, P.K.L. (2006) Mitochondrial DNA sequence analyses in Bornean sucker fishes (Balitoridae: Teleostei: Gastromyzontinae). Integrative Zoology, 1, 12-14.

Zohrah, H.S. \& Ramlee, H.S. (2007) A Guide to Wild Aquatic Fauna of Tasek Merimbun. Reprint with revised content of Zohrah \& Ramlee (2005), Brunei Museum Department, Kota Batu, 55 pp. 